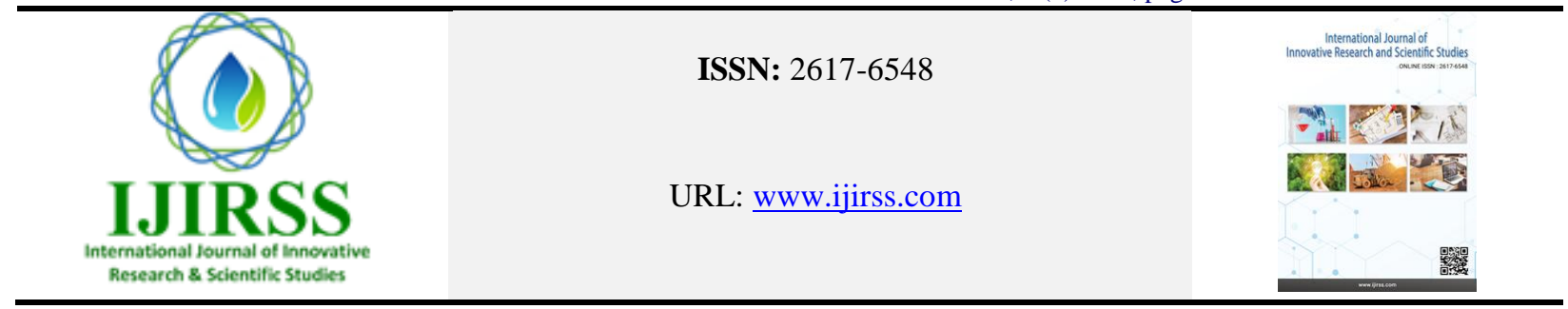

\title{
Effects of Urea Foliar Application on Growth and Yield of Green Pepper
}

\author{
Gulbuddin Gulab ${ }^{1}$, , Saidajan Attiq Abdiani ${ }^{1}$, Kifayatullah Kakar $^{2}$, Shafiqullah Aryan² \\ ${ }^{1}$ Horticulture Department of Agriculture Faculty, Nangarhar University, Nangarhar, Afghanistan \\ ${ }^{2}$ Agronomy Department of Agriculture Faculty, Nangarhar University, Nangarhar, Afghanistan \\ *Corresponding author: Gulbuddin Gulab (malyargulab@gmail.com)
}

\begin{abstract}
Vegetable crops require nutrients in various quantities for growth, development, and reproduction. Plants nutrients might be naturally available from soil or/ and atmosphere. However, modern cultivation needs artificial supplementation of nutrients. Green pepper is an important vegetable crop in several countries including Afghanistan. Irregular rates and methods of fertilizers application in green pepper production caused its yield to decrease. A study was conducted at the experimental farm of agriculture faculty; Nangarhar University in 2017 with traditional method (control), 1\%, 2\% and 3\% of urea foliar application treatments under the randomized complete block design, this study aimed to investigate and point out the best fertilizer application rate and method for green pepper production in Afghanistan, especially Nangarhar province. The control treatment increased plant height, fruit length, fruit weight, fruit yield and consequently net income compared to other treatments. However, $3 \%$ treatment had negligible differences with control; although $1 \%$ and $2 \%$ treatments got third and fourth positions, respectively. In $3 \%$ treatment, the urea was efficiently utilized with lower urea losses compared to the control treatment. Further researches should undertake to find out the proper application rates and methods for other chemical fertilizers
\end{abstract}

Keywords: Vegetables, Capsicum annuum, nitrogenous fertilizer.

DOI: 10.53894 /ijirss.v2i2.16

Funding: The authors appreciate the Higher Education Development Program (HEDP)/ organization for providing financial support to this research, agriculture faculty leading staff for their cooperation, and students of the mentioned faculty for their assistance.

History: Received: 23 April 2019/Revised: 14 May 2019/Accepted: 5 June 2019/Published: 12 June 2019

Licensed: This work is licensed under a Creative Commons Attribution 4.0 License (cc) EY

Acknowledgement: All authors contributed to the conception and design of the study.

Competing Interests: The authors declare that they have no conflict of interests.

Transparency: The authors confirm that the manuscript is an honest, accurate, and transparent account of the study was reported; that no vital features of the study have been omitted; and that any discrepancies from the study as planned have been explained.

Ethical: This study follows all ethical practices during writing.

\section{Introduction}

Green pepper (Capsicum annuиm L.) belongs to the Solanaceae family [1]. Capsicum species is well known as pepper, it is the world's second most popular vegetable after tomato [2]. Green pepper is cultivated in many countries including Afghanistan. It has 22 wild and 5 tamed varieties [3]. The fruit of green pepper is consumed in fresh and dried forms as a good appetizer and contains a variety of vitamins [4]. In many parts of the world, pepper is essentially valued for its pungency, nutrition and the pigment contents of the fruits [5]. All the plants, including green pepper, need sufficient and proper dose of nutrients for their proper growth which needs to be absorbed from soil or other sources. Nitrogen is one of 
the important nutrients for pepper growth. To consider its proper dose and application method; Guertal, [6] suggested $135 \mathrm{~kg} / \mathrm{ha}$ of nitrogenous fertilizer for higher yield of pepper.

Due to climatic and geographical reasons, the cultivated soils of Afghanistan are low fertile and deficient in nutrients; especially of nitrogen. Farmers supplementing nutrients through the application of nitrogenous fertilizers, but the application efficiency is low. Nitrogen $(\mathrm{N})$, Phosphorus $(\mathrm{P})$ and Potassium $(\mathrm{K})$ are the most important nutrients compared to other nutrients by crops. Basically, deficiency of $\mathrm{N}$ is serious in soil/plants compared to the rest two other nutrients because it can be produced through the decomposition of organic matter. At the same time, the dry and warm climatic condition of the country slows soil development processes and limits the organic matter content in the soil [7]. Nitrogen in the soil can be easily deteriorated by leaching and can be out of the benefits of the crop. Nowadays more than $80 \%$ of nitrogen is applied to field crops only through urea. Therefore, products knowledge about urea is of paramount importance. Urea is used in splits in the different active growth stage. Generally, in vegetable fields broadcasted over loose surface soil, sometimes covered by weeds that followed by immediately deep irrigation that much reduce the efficiency, while in some area due to the scarcity of irrigation water, application of urea through the water is impossible that might affect the crop yield.

The world is threatened by different types of pollutants as chemical fertilizer particularly nitrogenous fertilizer which is one of the polluting elements [8]. On the other hand, cost of chemical fertilizers is high which can be uneconomic for farmers if they used more than crops requirement. Furthermore, there is a significant need to identify the proper quantity of nitrogenous fertilizer and agriculture practices that could be adapted to the soil fertility and climate of the region. Currently in Afghanistan; particularly in Nangarhar province which confirms high yield of pepper; different quantities of fertilizers with different methods are applied in relevant to the soil and climate condition of the area. There is neither recommended method nor proper dose of nitrogenous fertilizer in pepper crops to increase the yield and results in decrease of hazards elements through reduction in fertilizer pollutions. Abdiani and Gulab [9] indicated that even though Afghan farmers are using about 0.17-0.2 million $t$ urea and 0.1-0.12 million $t$ of phosphate fertilizers annually from such amount, the huge percentage cannot be fully utilized by plants. Singh [10] reported that urea can be dissolved in water with a concentration of 2 to $4 \%$ and sprayed over crops during the nitrogen deficiency. Similarly, Sharma [11] approved the foliar application of $1 \%$ concentration of urea on vegetables.

In general, 60 to $90 \%$ of the total applied fertilizers are lost and the remaining 10 to $40 \%$ is taken up by plants [12] in this regard, the modification should be justified in term of required amount, time and application methods of fertilizers. Therefore, investigation and research were needed to elucidate whether or not, foliar application of urea is used as a modification to lead the system toward satisfaction. Based on the stated needs, the experiment has been conducted on pepper crop in Nangarhar province to identify the proper quantity and method of nitrogenous fertilizer application which ensures high productivity, economic efficiency, benefits to the farmers and decrease in environmental hazards. The objective of the research was to recommend proper nitrogenous fertilizers doze and method to pepper crops based on the area and soil productivity and to decrease the damage to the environment due to the excessive use of fertilizers. This research and dissemination of its results will pave the route for improvement of the fertilizers efficiency, especially urea. Moreover, it could be real information and reference for researchers, traders, and ecologists which would directly enhance the socio-economic development of the eastern region as well as the country.

\section{Materials and Method}

The experiment was conducted in research farm of agriculture faculty at Nangarhar University in 2017, applying the randomized complete block design (RCBD). Research farm was plowed with a deep plow (moldboard plow) and shallow plow (chisel plow) then divided into small plots by ridges in between. Capsicum annuum cv. Sindhi which is mostly cultivated in the eastern region was selected as plant material, seeds were sown in March 2017 (Hamal of 1396) and after one month the seedlings were transplanted to the plots, having $12 \mathrm{~m}^{2}$ area and 2 ridges (borders), the seedlings were planted on both ridges in two rows; $30 \times 50 \mathrm{~cm}$.

The attributes of the soil in $30 \mathrm{~cm}$ depth are outlined in Table 1. Soil texture particles were determined using the method of hydrometer by soil triangle. Soil $\mathrm{pH}$ was measured by a $\mathrm{pH}$ meter (6173 $\mathrm{pH}$ meter, Jenco Co., Taiwan). Electroconductivity was recorded through an EC meter (3251 COND/SAL/TEMP meter, Jenco Co., Taiwan). Phosphorus was quantified by spectrophotometer (SP-300, spectrophotometer, Optima, Co., Japan), and Potassium was measured with a flame photometer (PFP 7, flame photometer, Jenway Co., UK). Finally, the calcium carbonate was tested with the method described by Rowell [13].

In this experiment, nitrogenous fertilizer (urea) was applied in three growth stages (seedling transplantation, flowering and one month after flowering) in solid and spray forms and compared in 4 replications. Amount of urea and application method is shown in Table 2. In every treatment, $130 \mathrm{~g}$ di-ammonium phosphate, $\left(\mathrm{NH}_{4}\right)_{2} \mathrm{HPO}_{4}(\mathrm{DAP})$; a chemical fertilizer and 30kg farmyard manure (FYM); as a mixture of animal manure and plant residues were applied equally during seedbed preparation and urea was applied as per the quantity and application method specified in Table 2 . Weed control was conducted three times by hand physically. Plots were irrigated based on climate condition and needs of the soil. First harvesting was in May 2017 (Jawza of 1396) and continued to 8 times until the end of the season. During the growing season data such as plant height, and length and weight of fruit have been collected. After each harvesting, length and weight of 10 peppers which were randomly selected from each treatment were measured to calculate the average length and weight of the peppers. The collected data were analyzed using SPSS 13.0 software and then economic analysis of different treatments was evaluated and compared. 
Table-1.

Soil characteristics of Nangarhar University faculty of agriculture research farm

\begin{tabular}{l|l}
\hline Soil characteristics & Portion \\
\hline Texture Class & Sandy clay loam \\
\hline Clay texture & $25.20 \%$ \\
\hline Silt texture & $27.30 \%$ \\
\hline Sand texture & $47.68 \%$ \\
\hline $\mathrm{pH}$ & 7.8 \\
\hline Salinity EC & $0.045 \mathrm{dS} / \mathrm{m}$ \\
\hline Nitrogen & $250 \mathrm{mg} / \mathrm{kg}$ \\
\hline Phosphorus & $3.3 \mathrm{mg} / \mathrm{kg}$ \\
\hline Potassium & $118 \mathrm{mg} / \mathrm{kg}$ \\
\hline Calcium carbonate & $23.00 \%$ \\
\hline
\end{tabular}

Table-2.

Dose and application method of urea in pepper crops

\begin{tabular}{l|l|l}
\hline Treatments & $\begin{array}{l}\text { Urea } \\
(\text { g/plot })\end{array}$ & Application method \\
\hline Control & 255 & Solid and broadcast \\
\hline $1 \%$ & 30 & Spray \\
\hline $2 \%$ & 60 & Spray \\
\hline $3 \%$ & 90 & Spray \\
\hline
\end{tabular}

\section{Results}

There was a statistically significant difference in growth characteristics $(p<0.01)$ in height of plants, while no significant difference in size (length) of the fruit. The plant height, fruit length, and weight in control treatment were higher than in other treatments followed by $3 \%, 2 \%$, and $1 \%$ urea application (Table 3).

Table-3.

Plant height, length, and weight of fruit in different urea treatments

\begin{tabular}{l|l|l|l}
\hline \multirow{2}{*}{ Treatments } & $\begin{array}{l}\text { Plant } \\
\text { height }\end{array}$ & Fruit & Fruit \\
\cline { 2 - 4 } & $(\mathbf{c m})$ & $\begin{array}{l}\text { length } \\
\text { (cm) }\end{array}$ & weight (g) \\
\hline Control & $38.2 \mathrm{a}$ & 9 & 1.9 \\
\hline $1 \%$ & $34.0 \mathrm{~b}$ & 8.8 & 1.7 \\
\hline $2 \%$ & $36.8 \mathrm{a}$ & 8.9 & 1.8 \\
\hline $3 \%$ & $37.7 \mathrm{a}$ & 9 & 1.9 \\
\hline Significant Difference & $* *$ & NS & NS \\
\hline $\begin{array}{l}\text { Note: } * * \text { shows a significant difference at 1\% level by Fisher's LSD, same letters within the } \\
\text { column means no significant difference, while NS indicates no significant difference. }\end{array}$
\end{tabular}

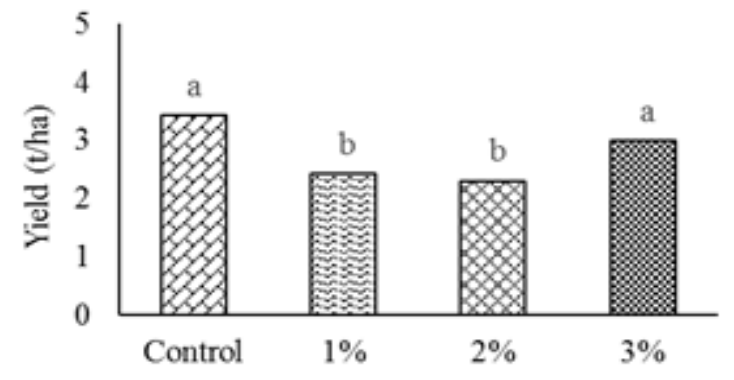

Dose of urea within treatments

Figure-1.

The yield of pepper $(t / h a)$ within different treatments of urea foliar application. Different letters show a significant difference at the 5\% level by Fisher's LSD. 
There was a significant difference in yield of different treatments in ton/hectare (t/ha), control treatment had the highest yield (3.424 t/ha)) and 2\% treatment had the lowest yield (2.31 t/ha), while 3\% and 1\% were (3t/ha) and (2.43 t/ha) respectively. It is notable that there was no significant difference between the yield of control and $3 \%$ treatments and in the same way $2 \%$ and $1 \%$ treatments (Figure 1 ).

Control treatment had the highest yield, while to be noted that considering the amount of urea application to the treatments, control received the highest, 3\% treatment 2nd and 2\% 3rd highest, while 1\% received the lowest amount of urea. Economic analysis and net income of different treatments are well exhibited in Table 4. Calculating the net income for the yields based on market prices for both urea and pepper in Afghani (Urea $\mathrm{kg}=30 \mathrm{AFN}$ and fresh pepper $\mathrm{kg}=80$ $\mathrm{AFN}$ ), it indicates that there is a slight difference between the net income of treatment $3 \%$ and control. It means 3 times more urea had been applied in control treatment than in 3\% treatment and the same way increases the expenditure by 3 times than the $3 \%$ treatment. It is mentionable that net income is directly proportional to the quantity harvest. Based on the urea fertilizer application, the control treatment received high urea following by $3 \%, 2 \%$, and $1 \%$ treatments; however, the yield was greater in control, $3 \%, 1 \%$, and $2 \%$, respectively. The income was highly associated with the yield rather than the amount of urea application, but the net income was affected by urea expenses.

Table-4

Economic analysis and net income of different treatments

\begin{tabular}{l|l|l|l|l|l}
\hline Treatments & Urea (kg/ha) & Yield (kg/ha) & Price of urea/ ha & $\begin{array}{l}\text { Income } \\
(\mathbf{A F N} *)\end{array}$ & Net income (AFN*) \\
\hline Control & 425 & 3424 & 12750 & 273920 & 261170 \\
\hline $1 \%$ & 50 & 2430 & 1500 & 194400 & 192900 \\
\hline $2 \%$ & 100 & 2310 & 3000 & 184800 & 181800 \\
\hline $3 \%$ & 150 & 3000 & 4500 & 240000 & 235500 \\
\hline *AFN; Afghanistan's currency (10Afghanes $\approx \$ 0.2)$ \\
Price of urea= 30AFN/kg and price of pepper $=80 \mathrm{AFN} / \mathrm{kg}$.
\end{tabular}

\section{Discussion}

Plant growth depends upon nutrients and in particularly available nitrogen in the soil [14] similarly, experiments indicate that growth of pepper and its fruit development depends on soil nitrogen as well as on the application of nitrogenous fertilizers [15]. This research also confirmed that the application of an increased quantity of nitrogenous fertilizer improves the growth of pepper as well as fruit development and the yield per unit land area. Even though not all of the applied nitrogenous fertilizer is consumed or absorbed by the plant, and a relatively good amount of this nitrogen is evaporated or leached which is no more available for plants. This relocation of nitrogen is considered economic loss and pollutes to the environment, which is against sustainable agriculture principles and can create threats to human health and living organisms in the future [8].

In economic analysis, we found that there is no significant difference in yield and net income between $3 \%$ and control treatments, while $425 \mathrm{~kg} / \mathrm{ha}$ urea was applied to the control and $150 \mathrm{~kg} / \mathrm{ha}$ to the $3 \%$ treatments. It is clearly indicated that, in control treatment, a considerable amount of nitrogen has been misplaced and a little amount of nitrogen was absorbed by pepper plants. However, in 3\% treatment most of the nitrogen was absorbed and very little amount of it is misplaced.

Application of nitrogenous fertilizer in different phases and growth stages not only makes nitrogen available for plants but also increases the effectiveness of the application and absorption. Research shows that application of nitrogenous fertilizer in different phases increases yields [16] and affects the quality of pepper fruit [17]. The quantity, time, and method of application are important factors affecting the growth and development. Thus, it is important to conduct similar further experiments to refer and identify proper time (phase), method and quantity of chemical fertilizers for future recommendations based on crop requirement and soil condition [18].

\section{Conclusion}

Type and fertility of soil and climate condition affect the availability and usage of nutrients in different ways are important factors to prepare nutrients especially nitrogen for plants. It is clear that nitrogen is misplaced and lost due to different factors. For an effective use of nitrogen, it is important to consider its proper type, application method and plant requirements for better growth with maximum fruit yield, and minimum nitrogen loss.

Our research clearly shows that $3 \%$ treatment had almost the same yield as the control treatment; whereas, the $1 \%$ and $2 \%$ treatments got the third and fourth positions. In addition, high quantity of urea was applied to the control treatment; urea was lost (leached or evaporated) which might pollute the environment. Finally, it is recommended that further experiments should be conducted to identify the proper quantities and approaches of using chemical, biological and organic fertilizers to enhance the domestic production of pepper and consequently increase national income.

\section{References}

[1] Y. Rodríguez, T. Depestre, and O. Gómez, "Efficiency of selection in pepper lines (Capsicum annuum), from four subpopulations, in characters of productive interest," International Journal of Agriculture and Natural Resources, vol. 35, pp. 2940, 2008.

[2] G. Benson, A. Obadofin, and J. Adesina, "Evaluation of plant extracts for controlling insect pests of pepper (Caspicum spp.) in Nigeria humid rainforest," New York Science Journal, vol. 7, pp. 39-43, 2014. 
[3] S. P. Toquica, F. Rodríguez, E. Martínez, M. C. Duque, and J. Tohme, "Molecular characterization by AFLPs of Capsicum germplasm from the Amazon department in Colombia," Genetic Resources and Crop Evolution, vol. 50, pp. 639-647, 2003.

[4] G. J. H. Grubben and O. A. Denton, Plant resources of tropical Africa 2. Vegetables. PROTA foundation. Wageningen, Netherlands. Leiden, Netherlands/ CTA: Backhuys Publ, 2004.

[5] H. Tian, C. Chunxiang, D. Shengmao, Z. Sheng, L. Shilei, X. Min, C. Wei, Z. Jian, L. Di, and Z. Hongyuan, "Analysis of vegetation fractional cover in Jungar Banner based on time-series remote sensing data," Journal of Geo-information Science, vol. 16 pp. 126-133, 2014.

[6] E. A. Guertal, "Preplant slow-release nitrogen fertilizers produce similar bell pepper yields as split applications of soluble fertilizer," Agronomy Journal, vol. 92, pp. 388-393, 2000. Available at: https://doi.org/10.2134/agronj2000.922388x.

[7] S. R. Rahmani, "Creating initial digital soil properties map of Afghanistan," Purdue University, Open Access Theses, Purdue ePubs, 2014.

[8] T. Agbede, "Tillage and fertilizer effects on some soil properties, leaf nutrient concentrations, growth and sweet potato yield on an Alfisol in southwestern Nigeria," Soil and Tillage Research, vol. 110, pp. 25-32, 2010. Available at: https://doi.org/10.1016/j.still.2010.06.003.

[9] S. A. Abdiani and G. Gulab, Strategy for wheat self-sufficiency in Afghanistan: Nangarhar University, Ministry of Higher Education (MoHE), 2016.

[10] A. P. Singh, Vegetable culture, A textbook. New Delhi: Kalyani Publ, 2004.

[11] R. R. Sharma, Propagation of horticultural crops. New Delhi, India: Kalyani Publ, 2015.

[12] D. Bhardwaj, M. W. Ansari, R. K. Sahoo, and N. Tuteja, "Biofertilizers function as key player in sustainable agriculture by improving soil fertility, plant tolerance and crop productivity," Microbial Cell Factories, vol. 13, pp. 1-10, 2014. Available at: https://doi.org/10.1186/1475-2859-13-66.

[13] D. L. Rowell, "Soil science: Methods and application," Journal of the Science of Food and Agriculture, vol. 66 pp. 513-576, 1994.

[14] N. C. Brady and R. R. Weil, "The nature and properties of soil," Agroforestry Systems, vol. 54, p. $249,2002$.

[15] J. Payero, M. Bhangoo, and J. Steiner, "Nitrogen fertilizer management practices to enhance seed production by Anaheim Chili'Peppers," Journal of the American Society for Horticultural Science, vol. 115, pp. 245-251, 1990. Available at: https://doi.org/10.21273/jashs.115.2.245.

[16] M. J. Shakouri, M. H. B. Keshavarzi, A. F. Abadi, and M. Lotfi, "The effect of N fertilizer and plant density on green peppers yield and its components," International Journal of Advanced Biological and Biomedical Research, vol. 2, pp. 586-590, 2014.

[17] G. Csilléry, "Pepper taxonomy and the botanical description of the species," Acta Agronomica Hungarica, vol. 54, pp. 151166, 2006. Available at: https://doi.org/10.1556/aagr.54.2006.2.5.

[18] A. H. Ahmadi, H. Jahantighi, and H. Rostami, "Study on the yield of sweet, green and salad pepper cultivars in Sistan," Seed and Plant Improvement Journal, vol. 20 pp. 259-262, 2004. 